\title{
«Creciendo en los brazos de la estampa»: estudio comparado entre el Coloquio de los perros de Cervantes y su continuación por Ginés Carrillo Cerón
}

\author{
Pablo Martín GonzÁlez*
}

\begin{abstract}
Resumen
Este artículo propone un estudio comparado entre el Coloquio de los perros de Cervantes y la continuación de Ginés Carrillo Cerón de 1635 centrándose en sus tres divergencias principales: la omisión en la segunda parte del vínculo temático entre El Casamiento engañoso y el Coloquio, las diferencias con que Cervantes y Cerón se aproximan al género picaresco y el rechazo por parte de Cerón de los elementos maravillosos del primer Coloquio. Estas discrepancias no solo nos permiten entender mejor el texto de Cervantes, sino también estudiar la problemática literaria e ideológica que planteaban sus novelas a los lectores del siglo XVII.

Palabras clave: Miguel de Cervantes; Coloquio de los perros; Novelas ejemplares; Ginés Carrillo Cerón; estética de la recepción.
\end{abstract}

Title: «Mushrooming in the Platen of a Printing Press»: Comparative Study between Cervantes' Dialogue of the Dogs and Ginés Carrillo Cerón's Sequel

\footnotetext{
Abstract

This article offers a comparative study between Cervantes' Dialogue of the Dogs and Ginés Carrillo Cerón's 1635 sequel focusing on its three main discrepancies: the omission of the thematic link between The Deceitful Marriage and the Dialogue in the second part, Cervantes and Cerón's different approach to the picaresque genre and Cerón's rejection of the marvelous elements from the first Dialogue. These discrepancies not only allow us to reach a better understanding of Cervantes' text, but also to study the literary and ideological quandaries that readers of the seventeenth century might have faced.

* Universidad de Salamanca. pablomarting@usal.es / ORCID iD: https://orcid.org/0000-00024861-5894.
} 
Keywords: Miguel de Cervantes; Coloquio de los perros; Novelas ejemplares; Ginés Carrillo Cerón; Reception Theory.

\section{Cómo citar este artículo / Citation}

Martín González, Pablo. 2020. «'Creciendo en los brazos de la estampa’: estudio comparado entre el Coloquio de los perros de Cervantes y su continuación por Ginés Carrillo Cerón». Anales Cervantinos 52: 255-281, https://doi.org/10.3989/anacervantinos.2020.010.

\section{LECTURAS MORALES E INMORALES DE «NUESTRO ESPAÑOL BOCCACCIO»: NOVELAR EJEMPLOS EN EL SIGLO XVII}

Cualquier estudio dedicado a documentar la recepción de las Novelas ejemplares en el siglo XVII debe detenerse, en primer lugar, en la controvertida cuestión de su ejemplaridad. Así pues, asuntos tan espinosos como la incierta naturaleza moral del texto o la tensión ética y estética entre el prodesse, el delectare y el movere no han dejado de avivar la atención y las sospechas de los estudiosos de este ambiguo ars praedicandi cervantino ${ }^{1}$.

Efectivamente, la vinculación que Cervantes establece desde el mismo título entre el discurso literario y el moral no hace sino invitarnos a contemplar sus textos a la luz de las motivaciones ideológicas que conformaban la fisonomía de la España áurea. Las Ejemplares, en tanto que creaciones literarias, reflejan «las transformaciones simbólicas que sufren ciertos contenidos sociales y religiosos» tales como el fenómeno sociocultural de lo ejemplar, en relación «con los circuitos y medios de distribución y recepción de imágenes valorativas, [y con las] descripciones de cosas consideradas económica o

1. Entre los numerosos estudios que tratan el tema de la discutida ejemplaridad de las Ejemplares hemos de remitir, en primer lugar, a Américo Castro, que desconfía de la lección moral que los relatos cervantinos puedan ofrecer atribuyendo la ejemplaridad prometida en el prólogo a un «Cervantes inventado por Cervantes» (1948, 331). Por su parte, Casalduero (1974), pionero en estudiar las doce novelas como una unidad de significado, nos ofrecerá una visión del conjunto como un intento por parte de Cervantes de confrontar el mundo real con el ideal de virtud del siglo XVII.

No todas las aproximaciones a la ejemplaridad apuntan hacia el contenido moral de los textos, sino que también hay un buen número de estudios que se centran en la ejemplaridad del estilo cervantino y en la plena consciencia del autor de estar creando algo nuevo. Entre ellos podemos remitir al análisis de Riley (1992), en el que la ejemplaridad será examinada como una exigencia del género de la novela corta que, junto al deleite, debía ofrecer también una lección moral, y al de Zimic (1996), que la interpretará como una virtud estilística de la colección de relatos, que reformula sus modelos literarios para ofrecer, como resultado, la novela corta moderna.

Por último, no debemos dejar de mencionar los acercamientos más recientes a esta cuestión, que se caracterizan por indagar en los antecedentes literarios a las novelas cervantinas para dilucidar el sentido que Cervantes le daba al término “ejemplar”. En este sentido, en el artículo de Darnis (2013), se nos ofrecerá una disección de estos cuentos a la luz de los conseja medievales para concluir que la ética cervantina está más cercana al gobierno de uno mismo que a la moralidad religiosa. 
moralmente valiosas» (Sánchez 1993, 19). Por este motivo, cualquier acercamiento a la obra cervantina, si pretende ser riguroso, deberá contar tanto con la incorporación de esos contenidos en el texto como con su recepción por parte de los lectores y oidores del siglo $\mathrm{XVII}^{2}$.

En este sentido, la continuación del Coloquio de los perros, que el procurador granadino Ginés Carrillo Cerón dio a la imprenta en 1635, nos ofrece un testimonio esencial para reconstruir la problemática literaria e ideológica que la ambigua ejemplaridad de las novelas cervantinas podía plantear a los lectores del Seiscientos. Así pues, a continuación, proponemos un estudio comparado entre el Coloquio de Cervantes y el de Cerón que, a la luz de sus muchas divergencias, va a permitirnos revisar en profundidad la ejemplaridad literaria y moral del original cervantino.

No obstante, antes de abordar el estudio de ambos coloquios, conviene que nos detengamos en algunas consideraciones sobre la vinculación de las Ejemplares con la novela corta y la literatura didáctica del siglo XVI, a fin de precisar el contexto de su recepción.

Así, regresando al título de esta compilación de relatos, hemos de reparar en la evidente antinomia genológica en la que Cervantes parece incurrir ${ }^{3}$. Si bien, como mencionábamos más arriba, en el adjetivo ejemplares adivinamos cierta vinculación con las prédicas medievales de los exempla, es decir, con la tradición retórica del cristianismo occidental salida del scriptorium; el sustantivo novela, sin embargo, hará evidente la vinculación de esta colección de cuentos con la controvertida novella italiana del Cinquecento, cuya finalidad didáctica fue puesta en tela de juicio por los teólogos y moralistas de la época 4 .

De esta manera, Cervantes advertirá en el prólogo a su colección «que si por algún modo alcanzara que la lección de estas novelas pudiera inducir a quien las leyera a algún mal deseo o pensamiento, antes me cortara la mano con que las escribí que sacarlas en público» $(1994,52)$, una prevención que inevitable-

2. A fin de profundizar en la figura del receptor de la literatura ejemplar, se recomienda acudir al artículo de Gómez Redondo (1998) sobre los lectores y oidores de los exempla medievales y de la literatura ejemplar áurea. Asimismo, el artículo de Frenk Alatorre (1982) ofrece una aproximación a la difusión oral de la literatura de los siglos XVI y XVII.

3. No deja de ser llamativo que Cervantes llamase insistentemente la atención sobre el componente moral de su texto en el que suponemos que es uno de los títulos descartados de su compilación de relatos: Novelas ejemplares de honestísimo entretenimiento (González Ramírez 2018, 63).

4. Para una ampliación de la disputa en torno a la novella italiana del Cinquecento y su relación con las Novelas ejemplares convendría revisar el volumen de Garrido Domínguez (2007) que nos presenta la innovación cervantina del relato corto en lengua española a la luz del estudio de sus antecedentes literarios y de los postulados teóricos de la novela corta italiana. A su vez, para una perspectiva más general en torno al fenómeno de la novella, remitimos al estudio de Colón Calderón (2001), en el que se documentan los autores, las obras y la recepción de la novela corta española en el siglo XVII, así como el de García de la Torre (1983) sobre la literatura didáctica en los Siglos de Oro y el de Prieto (1986), en el que esboza una historia de la prosa ejemplar áurea del siglo XVI desde las facecias hasta la novela corta ejemplarizante. A este respecto, también se recomienda acudir a los artículos de Rubio Árquez (2013), Martín Morán (2015) y González Ramírez (2016), que contextualizan la mala fama de la prosa breve italiana y la intervención de las autoridades en la creación y recepción de las obras. Por último, no podemos dejar de citar el volumen de Pabst (1972), en el que lleva a cabo un minucioso estudio de la novela corta deteniéndose, por supuesto, en Boccaccio y Cervantes. 
mente nos trae a la memoria la disputa en torno a la utilidad de la novela corta que estalló en la Italia contrarreformista y que no tardó en extenderse a España. Efectivamente, la expurgación del Decamerón de Boccaccio durante la segunda mitad del siglo XVI, así como el recrudecimiento de la censura sobre los novellieri, dio lugar a finales de siglo a una moralización generalizada de la novela corta (Vega Ramos 2013, 70) ${ }^{5}$. A este respecto, Rogelio Miñana nos revela las acusaciones que se vertían sobre este tipo de literatura:

El asedio a la literatura imaginativa, así pues, es total. Las objeciones se agrupan en tres bloques esenciales y difícilmente rebatibles: la falsedad intrínseca, la inmoralidad y la recepción exaltada de la ficción. La creación literaria no se corresponde con la realidad, sino que se compone de fingimientos y mentiras; muchos de sus contenidos son inmorales o pueden entenderse como contrarios a la moral; y muchos receptores sucumben ante los encantos y los excesos de un mundo sin límites fijos $(2006,24)$.

Si bien Cervantes parece afiliarse a la retórica contrarreformista con la insistente vindicación de la ejemplaridad de sus cuentos, tampoco dejará de identificarse con la tradición del entretenimiento deshonesto preconizada por Boccaccio ${ }^{6}$. Indudablemente, la antinomia que plantea Cervantes en el título de su compilación no pasará desapercibida a ojos del lector culto del siglo XVII, algo que queda demostrado en aquel descarado pero revelador ataque del anónimo Avellaneda en el prólogo de su Quijote apócrifo, cuando afirma que las Novelas cervantinas son «más satíricas que ejemplares, si bien no poco ingeniosas».

Sin embargo, conviene recordar también el que sería «el primer juicio crítico de las Novelas ejemplares» (Wardropper 1982, 153), es decir, las palabras que el censor fray Juan Bautista Capataz le dedicó a la obra en la aprobación datada en julio de 1612. El religioso afirmará que estos relatos

5. Conviene recordar que en la Pragmática de 1558, que reguló la producción y comercio de libros en Castilla hasta la caída del Antiguo Régimen, se exigía la revisión de aquellos libros «sospechosos y reprobados, o en que haya errores o doctrinas falsas, o que fueren de materias deshonestas y de mal ejemplo, de cualquier manera o facultad que sean, en latín o en romance» (Lucía Megías 1999, 206). Aparte del trabajo de Lucía Megías, a fin de profundizar en el impacto de la Pragmática de 1558 en la literatura peninsular, urge acudir a los estudios al respecto de Utrera Bonet (2013), en los que a partir de los libros del siglo XVI conservados en el Fondo Antiguo de la Biblioteca de Sevilla se evaluará la labor de legislación y censura que se dio durante el reinado de Felipe II, y por otro lado, al de Vega Ramos (2013), en el que se revisa el estatus de la novela corta frente a las autoridades españolas, italianas y portuguesas.

6. Conviene recordar que, a la altura del siglo XVII, la Retórica había dejado de ser asociada con aquella ratio dicendi ciceroniana que la identificaba con el discurso recto en cualquiera de las artes para, en su lugar, pasar a identificarse mayoritariamente con la ciencia literaria. El artículo de Abad resume la vinculación de la Retórica con la Poética a lo largo de la historia aclarando que: «Aunque Roland Barthes mantiene que la Retórica se hizo arte en la creación poética, más bien resulta que la poética se retorizó: en efecto lo literario es una imitación mediante el lenguaje, pero imitación que posee una especie propia de persuasión» (1987, 28). Con «retórica contrarreformista», por tanto, pretendemos hacer hincapié en el componente persuasivo del discurso literario ejemplarizante. Véanse a este respecto los estudios de Rico Verdú (1973) y García Berrio (1977) sobre la Retórica de los siglos XVI y XVII y, a un nivel más general, el estudio de Spang (2005). 
ofrecen «un entretenimiento honesto» y que «la verdadera eutrapelia está en estas Novelas porque entretienen con su novedad» y «enseñan con sus ejemplos a huir vicios» $(1994,45)^{7}$. De hecho, el propio Cervantes llamará la atención sobre las virtudes eutrapélicas de sus textos en el prólogo afirmando:

\begin{abstract}
$\mathrm{Si}$, que no siempre se está en los templos, no siempre se ocupan los oratorios, no siempre se asiste a los negocios por calificados que sean. Horas hay de recreación, donde el afligido espíritu descanse; para este efecto se plantan las alamedas, se buscan las fuentes, se allanan las cuestas y se cultivan con curiosidad los jardines $(1994,52)$.
\end{abstract}

En efecto, Cervantes defenderá el honesto entretenimiento que ofrece su colección de relatos y, al mismo tiempo, se alejará de los elogios estrictamente morales de Capataz al ofrecer una diversión catártica que propone «el distanciamiento interno [de la opresión, de las funciones y de las rutinas cotidianas] que nace de la actitud estética del juego de poder hacer libremente lo que en el resto de ocasiones hay que hacer en serio» (Jauss 1986, 34) ${ }^{8}$.

Así las cosas, resulta obvio que la novela corta planteaba un problema crucial a ojos de la Contrarreforma, un problema relacionado con su interpretación. El desaliñado retrato que la prosa de los novellieri esbozaba del clero, así como su ineficacia para reforzar los lazos del pueblo con la comunidad religiosa, a través de una suerte de catarsis que facilitase la sumisión al Estado, eran reemplazados en las obras de entretenimiento por un deleite que, a pesar de no estar reñido con el docere horaciano, era condenado como nocivo por inmoral. En este sentido, podemos acudir a las palabras de Hans Robert Jauss en torno a la producción y recepción de la literatura ejemplar en la Edad Media:

Ya los primeros padres de la Iglesia -que no eran partidarios del arte-hacían, sin embargo, una excepción, en lo que se refiere al uso de los poetas paganos, que narran exempla de palabra y de obra. La apelación al sentido ejemplar, en virtud de la cual san Basilio escribió su apología, sirvió para justificar,

7. El Diccionario de la Lengua Española define “eutrapelia” como «Virtud que modera el exceso de las diversiones o entretenimientos». No obstante, Aristóteles en su Ética Nicomaquea, texto de donde procede el término que en las ediciones españolas se traduce como "agudeza", se referirá, en su definición, a la propia etimología griega de la palabra: «A los que divierten a los otros decorosamente se les llama ingeniosos, es decir, ágiles de mente, pues tales movimientos se consideran notas de carácter, y lo mismo que juzgamos a los cuerpos por sus movimientos, lo hacemos también con el carácter» (Ética Nicomaquea, IV.8 1128 10-1128 14 ).

8. En relación a ello, hemos de recordar que la catarsis, en tanto que identificación estética del lector o del oyente con los modelos de comportamiento representados, será un elemento decisivo en la comunicación del contenido ejemplar de la literatura moralizante. No obstante, Jauss llamará la atención sobre los peligros que la función comunicativa de la experiencia estética planteaba de cara a las autoridades religiosas y políticas pese a su potencial utilidad ideológica, afirmando que la catarsis tenía la capacidad «de destruir la inhibición cotidiana o de llevar al espectador a una identificación moral con una acción ejemplar o de hacerlo perseverar en el simple placer de mirar, o de hacerle entrar, mediante la identificación emocional, en un comportamiento colectivo manipulado», unas cualidades que no tardaron en convertirse «en eje de una polémica dirigida (en nombre de la autoridad religiosa, de la moral social o de la razón práctica) contra los efectos incontrolados del arte» $(1986,164)$. 
durante siglos, la colección, registro y transmisión de la tradición narrativa más heterogénea y contribuyó también a extender la literatura de ficción, que, con una aplicación moral, solía iniciar todas las novelas del Medievo y que garantizaba, incluso, la farsa frívola o escatológica $(1986,88)$.

A este respecto, es conveniente llamar la atención sobre la benevolencia con que los mecanismos de censura oficial leyeron el texto cervantino. Frances Luttikhuizen nos recuerda que las Novelas ejemplares no sufrieron censura oficial, sino que, de hecho, tanto la aprobación eclesiástica como la del Consejo Real se apresuraron a autorizar el texto. Una permisividad que Luttikhuizen atribuye a la condición de obras de entretenimiento de las Ejemplares, es decir, libros inofensivos frente a los que la censura, según afirma, se mostraba particularmente tolerante $(1997,165)^{9}$. Sin embargo, tal y como afirmaba Jauss a la luz de las ficciones medievales, la sola condición de libros de entretenimiento de las Novelas ejemplares no las redimía en modo alguno de la censura, sino que, por el contrario, serían sus virtudes eutrapélicas, es decir, esa recurrente «apelación al sentido ejemplar» las que realmente las eximiría de las sanciones.

Sin embargo, a pesar de esta insistente (y algo evasiva) aserción a la corriente de la prosa moralizante, creemos poder afirmar que Cervantes era consciente de que la verdadera ejemplaridad que ofrecen sus relatos no era tanto de índole moral como estilística ${ }^{10}$. Espejo de futuros ingenios, estas novelas serán también ejemplares por sus audacias formales y su iconoclastia genológica $^{11}$. Más interesado en el delectare que en el prodesse, Cervantes trataba de habilitar un nuevo camino en la literatura española, pero debía amoldarse a las exigencias de un sistema autoritario que, controlando la imprenta, controlaba también la producción simbólica.

Esta diatriba literaria e ideológica se pone especialmente de relieve al cotejar la más controvertida de las Novelas ejemplares, el Coloquio de los perros, con la prolongación firmada por Ginés Carrillo Cerón. Si los conflictos en

9. Véase el artículo de González Ramírez (2018), que ofrece una interesante perspectiva sobre la flexibilidad de los censores frente a las obras de entretenimiento, centrándose particularmente en la polémica de los novellieri y en las Ejemplares de Cervantes.

10. A este respecto, véase el estudio introductorio a las Novelas ejemplares de González de Amezúa y Mayo (1956), donde evalúa las innovaciones temáticas y formales instigadas por Cervantes en la prosa europea del siglo XVII.

11. Esta doble ejemplaridad ética y estética ha sido defendida, entre otros, por Antonio Rey Hazas quien, en paralelo a la intencionalidad moral del Coloquio de los perros, destaca el virtuosismo técnico de Cervantes y su inventiva literaria: «[El coloquio de los perros] parece fruto de la reflexión inteligentísima de un escritor sin par, que comienza planteándose el problema de qué es la novela picaresca y acaba por crear, en inevitable conjunción de vida narrativa, la teoría y la práctica literarias de la novela, sin más adjetivos» $(2003,405)$. De hecho, recordemos las aseveraciones del propio Cervantes en el prólogo: «Y es así, que yo soy el primero que he novelado en lengua castellana; que las muchas novelas que en ella andan impresas, todas son traducciones de lenguas extranjeras, y éstas son mías propias, no imitadas ni hurtadas» $(1994,52)$. No obstante, conviene aclarar que no pretendemos reducir la importancia del componente ejemplar de las novelas cervantinas, tan solo subrayar que Cervantes parece plenamente consciente de que ese ejemplo provechoso que puede extraerse de cada uno de estos relatos no solo es de orden moral. 
torno a la prosa breve del Cinquecento y las reflexiones de Jauss sobre la heterogeneidad de los exempla nos conducían inevitablemente a revisar con suspicacia la ejemplaridad cervantina, el ejercicio de «reescritura oblicua» (Genette 1989,247$)$ que lleva a cabo Cerón sobre el Coloquio original nos permitirá aproximarnos a las secciones más controvertidas del relato de Cervantes.

A pesar de su mala fortuna editorial y de la escasa atención que cuatro siglos después parece estar despertando entre los estudiosos de las Ejemplares, la secuela de Cerón nos permitirá analizar el proceso de comunicación literaria al completo pues, regresando a Jauss, en ella la experiencia estética del texto original ha sido convertida en algo nuevo, una nueva representación que nos será útil por su valor negativo y su pulsión parricida hacia la obra original $^{12}$. La segunda parte del Coloquio de los perros es un perfecto ejemplo de aquello que Gerard Genette denominó «continuaciones infieles, o asesinas», pues desborda «la categoría de la imitación seria hacia la de la trasposición, e incluso de una variante muy fuerte y a veces muy agresiva, de la trasposición, que es la corrección temática, o la refutación» $(1989,244-245)$, evidenciando las tensiones que podía suscitar la obra original frente a las estructuras sociales, políticas y, sobre todo, culturales del Barroco hispano. La reescritura de Cerón implica, en resumidas cuentas, una revisión de la noción de lo ejemplar en el original cervantino planteando, de esta manera, una disputa en torno a la traducción simbólica de ciertos contenidos morales.

\section{2. «SI NO NOS HA DEJADO ESTE BENEFICIO DEL HABLA»: ESTUDIO COMPARAdo ENTRE el Coloquio De Cervantes y SU CONTINUACión POR GINÉS CARRILlo CERÓN}

\subsection{Hacia una poética de la continuación literaria: Ginés Carrillo Cerón, continuador de Cervantes}

Este ejercicio de prolongación del texto original se integra en un panorama literario en el que la praxis de la continuación era harto habitual ${ }^{13}$. A pesar de

12. Efectivamente, pocos estudiosos han abordado la continuación de Ginés Carrillo Cerón, no obstante, podemos remitir a la ya citada edición de la Segunda parte del Coloquio de los perros a cargo de Abraham Madroñal (2013), en la que, aparte de un detallado análisis de la continuación, incluirá los paratextos que acompañaban al volumen original. Por otro lado, también aconsejamos acudir a los artículos de Cotarelo (1925), en el que atestigua el descubrimiento de la obra, y a los de Madroñal (2011) y Lauer (2016). También hemos de llamar la atención sobre el estudio de Bĕlič (1977) que, aunque centrado en la estructura del Coloquio original, menciona la continuación de Cerón y discute su pertinencia.

13. Conviene que, aparte de la secuela firmada por Cerón, nos refiramos a la continuación perdida del licenciado Luis de Belmonte, tal y como lo documenta González de Amezúa y Mayo (1912, 224). Por otro lado, para ahondar en las continuaciones literarias cervantinas hemos de remitir a la compilación de Jurado Santos (2005) de obras teatrales del siglo XVII derivadas de la narrativa de Cervantes, y también a los volúmenes editados por Mata Induráin sobre continuaciones cervantinas 
la escasez de estudios que abordan el tema de las continuaciones en la literatura española bajomedieval y altomoderna, es evidente que se trató de un fenómeno bastante extendido y para el que podemos aducir ejemplos sobradamente conocidos que van desde la segunda Celestina de 1536 por Feliciano de Silva hasta el Quijote de Avellaneda de 1614, pasando por el Lazarillo de 1555 o el Guzmán de Alfarache de $1604^{14}$. Tal proliferación de continuaciones, entre las que evidentemente debemos incluir la segunda parte del Coloquio de los perros de Cerón, será fruto del desarrollo de la imprenta y de la progresiva consolidación y estabilización de la noción de autor, en detrimento del carácter anónimo y/o colectivo de la autoría medieval. Así pues, podemos aproximarnos a grandes rasgos al fenómeno de las continuaciones literarias como un producto del tránsito de la Edad Media a la Edad Moderna en materia de comunicación y representación literarias. «La práctica de la continuación -nos recuerdan David Álvarez Roblin y Oliver Biaggini- es un importante testimonio de la tensión entre una tendencia a atribuir una obra a un autor y otra tendencia, en parte heredada de la época medieval, que deja al receptor la posibilidad de apropiarse del texto ajeno» $(2017,7)$.

Ginés Carrillo Cerón, en tanto que autor alógrafo (es decir, continuador de la labor de un autor principal $)^{15}$, parece cumplir una doble función: por una parte, contribuirá a la construcción de un canon literario al remitir a una obra anterior, a la que reivindica como referente; por otra, se distanciará del texto original negándolo, modificando su sentido a fin de adecuarlo a sus propios intereses.

Además, no debemos olvidar que, aunque la filiación del Coloquio de los perros al género de la picaresca ha sido y es harto discutida, es posible detectar ciertos rasgos formales de este género en la novela de Cervantes, los cuales parecen exigir una prolongación del texto original ${ }^{16}$. Por lo tanto, hemos de abordar aquello que, siguiendo a Hanno Ehrlicher, podíamos denomi-

en la narrativa (2013) y en el teatro (2012). Por su parte, la aproximación intermedial de López Navia (2005) nos ofrece un acercamiento tanto a las recreaciones hechas por el propio Cervantes con respecto a sus antecedentes como a las obras derivadas de la narrativa cervantina con especial hincapié en el Quijote.

14. Para profundizar en el estudio de las continuaciones literarias de los siglos XVI y XVII es conveniente acudir al estudio de Hinrichs (2011) y al volumen coordinado por Álvarez Roblin y Oliver Biaggini (2017). Para una aproximación a las reescrituras y continuaciones cervantinas véase Grilli (2004).

15. Emplearemos el término "alógrafo", junto a Robin y Biaggini, para calificar la labor de Cerón que, siguiendo la terminología de Genette, se refiere a los cuerpos metatextuales y paratextuales no realizados por el autor principal. Las intervenciones alógrafas (tales como los prólogos, las anotaciones o, incluso, las ediciones críticas) sirven de comentario a un texto principal. En este sentido, en tanto que la segunda parte del Coloquio de los perros nos servirá de comentario al Coloquio original, lo consideraremos como una contribución alógrafa pues establece una relación interactiva entre el autor y el lector que tiene como centro el Coloquio original.

16. En torno al discutido carácter picaresco del Coloquio, se aconseja revisar el artículo de Rodríguez Guridi (2008), en el que, tras un inventario de las muchas infracciones de la normativa genológica picaresca por parte de Cervantes, se cuestiona la pertenencia de la obra a este género. Por otro lado, los estudios de Riley (2011) y de Montauban (2003) se remontarán a los antecedentes del Coloquio cervantino a fin de dilucidar la filiación genológica del texto. 
nar como «continuabilidad estructural de la picaresca» $(2017,189)$. Nos referimos a una serie de condiciones formales que se dan en la obra original haciendo que esta consienta e incluso reclame una prolongación. Entre estas características estructurales podemos señalar, por ejemplo, el empleo de la forma autobiográfica consolidada por Mateo Alemán, así como el frecuente uso de la narración en primera persona ${ }^{17}$. Estos rasgos obligan a dejar el relato del pícaro en suspenso o a concluir con abruptos desenlaces en los que el final de lo narrado confluye con el presente de la narración. La peculiar tentativa picaresca de Cervantes, aunque alejada de otros muchos rasgos de este género de los que nos ocuparemos más adelante, parece cumplir con estos dos principios estructurales. Asimismo, conviene recordar que Cervantes concluía su Coloquio recurriendo a uno de los lugares comunes más afamados de la picaresca, la promesa de una segunda parte. Una promesa a la que Cerón regresará de manera explícita al inicio de su relato en el que, tras el título en el que se nos informa de la condición de la obra como «Segunda parte de la que hizo Miguel de Cervantes Saavedra en sus Novelas», Cerón aclara:

Como queda referido en la primera novela o coloquio que tuvieron Berganza o Cipión, perros de Mahúdes, que el alférez Campuzano refirió al licenciado Peralta, y fueron a recrearse al Espolón otro día, después de comer.

Dijo el alférez al licenciado Peralta:

-Señor licenciado, aunque el coloquio que a v. m. referí ayer habían tenido los dos perros Berganza y Cipión v. m. lo tuvo por fábula o que yo, como tenía el entendimiento tan agudo de comer muchas pasas y almendras, lo soñé. Ello séase como se fuere, yo le prometí a v. m. de escribir lo que la segunda noche que estos dos perros, o lo que son, tornaron a conversar y lo he recopilado y escrito en la mejor forma que he podido; si v. m. está desocupado y quiere entretenerse un poco, aunque sea tiempo malgastado, yo se lo leeré $(2013,113)$.

De hecho, en los paratextos Cerón parece enfatizar el carácter «subalterno» (Genette 1989, 246) de su labor como continuador ${ }^{18}$. De esta manera, en la primera línea del prólogo a las Novelas de varios sucesos en ocho discursos morales podemos leer las que también serán las primeras palabras laudatorias

17. Véase a este respecto el estudio de Lázaro Carreter (1970), en el que propone una reformulación del concepto de picaresca a través de la morfología y la estructura del género. También se aconseja acudir al artículo de Gandía Barceló (2018), en el que propone un estudio de la construcción de los finales de los relatos picarescos abordando el tema de su continuabilidad.

18. El término "subalterno" siguiendo, de nuevo, la terminología de Genette, podemos traducirlo como aquella labor que está «al servicio de otra cosa» y que, por tanto, «se considera injustamente como intelectualmente inferior» $(1989,311)$. En este sentido, Genette se referirá a la praxis de las continuaciones infieles como una reacción del continuador frente a su labor subalterna en los siguientes términos: «Prácticas mixtas, pues, o ambiguas, de las que aparecerán más casos. Son inevitablemente las más interesantes y las más logradas, pues ni que decir tiene que un artista un poco dotado, cualquiera que sea su respeto hacia un gran maestro, no puede sentirse satisfecho con una tarea tan subalterna como la simple continuación» $(1989,246)$. 
hacia el maestro alcalaíno: «Bien cierto estoy, lector destas Novelas, que poco me importa llamarte amantísimo, como usó en las suyas Miguel de Cervantes Saaavedra, aquel prodigio de ciencia y que en esta materia se aventajó a todos, ni otros epítetos, para que dejes de decir lo que te pareciere» $(2013,107)$. Cerón, sabiéndose un epígono de Cervantes, convertirá la admiración en un mecanismo retórico al servicio de la captatio benevolentiae.

Por otro lado, al comienzo de su narración y a modo de topos humilitatis, Cipión elogiará el relato de su compañero Berganza: «Sete decir que fue tan prodigiosa y tan bien dicha, con tan buenos sucesos y tan graciosos, que temo mucho entrar a contar los míos. ¿No has visto cuando ha corrido un caballo muy bien y corre otro que por bien que lo haga parece mal?» $(2013,114)$. Y, una vez concluida la lectura de este segundo Coloquio, el Licenciado Peralta afirmará que «Bien se echa de ver que Berganza tiene más discurso y más elegancia, pero v. m. no debe darle colores, sino decirlo meramente como ellos lo dijeron» $(2013,154)$, eximiendo al Alférez Campuzano (y, por extenso, al autor real de la novela) de cualquier responsabilidad sobre la obra, atribuyendo, en su lugar, sus defectos de estilo al discurso de Cipión, del que efectivamente Campuzano es un mero transcriptor.

Sea como sea, la prolongación que Cerón nos propone del texto cervantino, pese a la evidente admiración que el epígono granadino profesa por su maestro, no es sino, en palabras de Genette, una modificación del plan narrativo, el ritmo y la acción del primer Coloquio $(1989,245)$. El difícil equilibrio entre la familiaridad y la novedad con que se procura construir toda continuación literaria se verá complementado en esta segunda parte con los intentos del continuador por eludir cualquier pasaje inverosímil, deshonesto o poco ejemplar, lo que enfatiza la lejanía de la secuela con su precursor. A pesar de que su continuación está desprovista de cualquier revisión irónica del texto de Cervantes y no contempla un fin vejatorio para con el original (a diferencia del Quijote apócrifo), algunas de las modificaciones que Cerón opera sobre su hipotexto evidenciarán los espacios de tensión que se generan no solo entre el epígono y su maestro, sino también entre la fantasía cervantina y los particulares sistemas de significación de la cultura del Seiscientos. Así pues, a continuación, proponemos una revisión de las tres principales divergencias que la secuela de Cerón plantea sobre el texto de Cervantes, a saber: la omisión de las correspondencias temáticas entre el Coloquio y El casamiento engañoso, el diferente grado de vinculación con el género picaresco y el rechazo a la estética cervantina de lo monstruoso y lo feo.

\subsection{El casamiento engañoso, marco narrativo del Coloquio}

Como es bien sabido, cualquier aproximación al Coloquio de Cervantes deberá partir del estudio de la relación entre esta y otra novela ejemplar, $E l$ casamiento engañoso, que en el volumen original sirve de marco narrativo al 
diálogo entre Cipión y Berganza. El vínculo entre ambas novelas no ha dejado de atraer la atención de los estudiosos, que han debatido extensamente si han de ser examinadas como dos relatos autónomos o si, por el contrario, conforman una unidad orgánica ${ }^{19}$. Sin embargo, Carrillo Cerón no recuperará en su Coloquio la fábula de El casamiento engañoso, por lo que podemos deducir que las dos novelas eran contempladas en su época como unidades de significado independientes. No obstante, Cerón reutilizará a los personajes de la novela (el Alférez Campuzano y el Licenciado Peralta) recuperando también el artificio narrativo con que Cervantes nos presentaba su Coloquio.

De esta manera, aunque Cerón omite las correspondencias temáticas entre ambas novelas, será consciente de los beneficios retóricos que puede reportarle este preámbulo a la retrospección autobiográfica de Cipión. Efectivamente, al reutilizar parcialmente el marco narrativo cervantino, Cerón se distancia, como en su momento hizo Cervantes, de las murmuraciones y semblanzas satíricas en que incurren los elocuentes alanos a lo largo de su plática; pero este preludio también le será útil para dotar al relato de la mayor verosimilitud posible. Así pues, situando a Campuzano en el papel de transcriptor del prodigioso y a todas luces imposible diálogo entre los dos canes, Cerón se pertrechará ante los reproches a la credibilidad de su novela.

De hecho, el continuador recurrirá también a la convalecencia de Campuzano en el hospital de la Resurrección de Valladolid, donde parafraseando el texto cervantino, el alférez recuerda las dudas que despertó el diálogo entre Cipión y Berganza en el Licenciado Peralta, quien «lo tuvo por fábula o que, como [Campuzano] tenía el entendimiento tan agudo de comer muchas pasas y almendras» $(2013,111)$ lo atribuyó a un vívido delirio del alférez. Cerón, al rememorar por boca de Campuzano las posibilidades que planteó el escéptico Peralta para explicar la causa de lo que aquel decía haber oído durante su convalecencia, mantendrá abierta la posibilidad de que todo se trate realmente de un sueño del transcriptor.

El uso que Cerón hace de los personajes de El casamiento engañoso será, por consiguiente, puramente técnico y responderá a una planificación retórica evidente, ya presente en el texto de Cervantes, destinada a conceder a la novela un mínimo de verosimilitud pese a lo insólito de lo narrado. En definitiva, el marco narrativo del Coloquio de Cerón hace explícita la doble disyuntiva, moral y estética, a la que se enfrentaba la novela corta en las primeras décadas del siglo XVII.

19. La disputa en torno a si la colección de novelas de Cervantes cuenta con once o doce relatos ha sido harto discutida por la crítica. Así, podemos remitir al estudio de Casalduero (1974), que defiende que las dos novelas constituyen una misma unidad de significado y que, por consiguiente, las Ejemplares estarían formadas por once novelas y doce ejemplos. Asimismo, Parodi (2002) contemplará los doce relatos del conjunto como una sola novela cohesionada formal y temáticamente que encontrará su máxima expresión en el binomio Casamiento-Coloquio. Entre los estudios que descartan la unidad de las dos novelas podemos remitir a Pabst (1972) y a Murillo (1988), que si bien llaman la atención sobre los beneficios técnicos de la inclusión del Coloquio dentro del Casamiento, rechazarán cualquier clase de vínculo entre ambas. 
La literatura áurea no solo debía ostentar una moral impecable con el fin de superar las sanciones inquisitoriales, sino que también debía de cumplir con los preceptos teóricos del momento de acuerdo a los que se elaboraba el discurso literario. Como es bien sabido, la verosimilitud es, desde la Poética aristotélica, una de las cualidades esenciales de cualquier creación literaria, pues posibilita la catarsis y habilita la función comunicativa de la experiencia estética del texto ${ }^{20}$. Además, en tiempos de Cervantes, fue una de las cualidades redentoras de la ficción no solo al presentar de manera creíble unos hechos de acuerdo con la verdad histórica, sino también, como es nuestro caso, en consonancia con una verdad moral, tal y como señala Rogelio Miñana:

Los dos extremos de autenticidad y mendacidad moral caben sin duda en un mismo continente, la ficción. Desde muy temprano se insiste, por ese motivo, en el escaso margen que media entre ficción y verdad moral. Las fábulas de Esopo son un ejemplo permanente de cómo la mentira más evidente puede contener un trasfondo moral o filosófico auténtico (2006, 29).

No obstante, al prescindir por completo de la fábula de El casamiento engañoso, es decir, de la ejemplar conclusión a la que nos conduce el fallido matrimonio entre Campuzano y doña Estefanía de Caicedo, Cerón excluye asimismo la ambigüedad del Coloquio original. Lo que ahora empezamos a vislumbrar a través de esta divergencia temática entre los dos coloquios es solo el principio de un dilema ideológico y literario al que, según creemos poder afirmar, se enfrentó Cerón en su tarea como continuador de la novela ejemplar cervantina.

Efectivamente, El casamiento engañoso no solo será utilizado como marco narrativo para expiar las herejías cervantinas con respecto a la verosimilitud del relato, sino que también ha de ser contemplado como un preámbulo temáticamente cohesionado con el Coloquio ${ }^{21}$. Ambas novelas estarán enla-

20. A este respecto, conviene recordar las palabras de Ife en torno a la construcción de la verosimilitud en el Coloquio: «The point of the Colloquy is to accomplish a daring sleight of hand: to use the credibility and plausability of what the dogs allegedly said as a guarantee of the fact that they did actually speak. [...] In the process Peralta is put in a position where anything he says about the Colloquy as a piece of literature [...] can only serve to reinforce the illusion that Campuzano is trying to create: to talk about the Colloquy is to talk about what the dogs said, since there is nothing in the Colloquy except what the dogs said. By having Peralta read the dialogue silently to himself, Cervantes is suggesting that there are some kinds of persuasion that only the written word is capable of carrying off» $(1985,62)$.

21. Así, Blasco Pascual se referirá a la intención de Cervantes al incluir historias intercaladas en el Quijote, llegando a unas conclusiones que perfectamente podemos aplicar a las Ejemplares: «Las palabras con que el narrador del Quijote, en la segunda parte, hace el elogio de la gala y artificio de esos paréntesis narrativos, que interrumpen el natural desarrollo de las aventuras del protagonista, apuntan precisamente hacia el error de leer las novelas interpoladas como historias independientes a la de don Quijote [...] Quienes no saben apreciar los valores de estas novelas, al hallarlas insertas en el cuerpo de una fábula mayor que las integra, no han comprendido correctamente su función» (2005, 120-121). 
zadas por un motivo fundamental: «El mal o más exactamente la maldad humana que Berganza encuentra, en formas y manifestaciones más variadas, en todas las "aventuras" que le depara su azarosa existencia» (Bělič 1977, 86) y que asimismo encontrará el alférez, no solo en el fraudulento matrimonio con doña Estefanía, sino también en su propia persona pues, a través de Peralta, sabemos que Campuzano es un consumado timador.

La regeneración moral que sufren tanto Campuzano como Berganza en sus respectivas historias, y que Cervantes nos ofrece en la forma de mise en abyme al enlazar ambas novelas, será el vínculo temático que haga de los dos relatos un todo orgánico. Berganza sufrirá una «evolución psíquico-moral» a lo largo de su narración, consecuencia de su paso por la «escuela de la vida» (Bělič 1977, 87) y Campuzano, al que vemos por primera vez saliendo del hospital de la Resurrección, se regenerará a través de la experiencia catártica que le produce escuchar, como si asistiese a la representación de un entremés, el diálogo entre los dos perros durante una noche de insomnio. En este sentido, Ruth El Saffar llamará la atención sobre los paralelismos entre la vida del perro y la del alférez:

The story the man tells of his own failed search for a place within the upper reaches of society is mirrored in the dog's account of his service to men of increasing status within the social order, his confrontation with corruption and hypocrisy at its heart, and his subsequent journey among the outcast and penniless. For man and dog, the hospital is both an ending and a beginning (El Saffar 1976, 84).

Los tres planos de realidad que Cervantes conjuga en estas dos novelas, El Casamiento y el Coloquio (Cabrera 1972, 51), quedarían, de esta manera, interconectados a través del perfeccionamiento moral, en primer lugar, de Berganza, alumno de la escuela de la vida, y de Cipión, su interlocutor; en segundo lugar, de Campuzano, oidor (o quizá creador) de la retrospección autobiográfica del alano, y de Peralta, primer lector del Coloquio trascrito por el alférez y, en tercer y último lugar, del lector de las Ejemplares que, a través de un proceso de catarsis (o quizá catastasis), habiendo alcanzado «el artificio o la invención del Coloquio» habrá recreado también, en palabras de Peralta, «los ojos del entendimiento» $(1994,359)^{22}$. Una construcción, la de «ojos del

22. Recordemos que Jauss, en deuda con Aristóteles y Gorgias, entendía la catarsis como «aquel placer de las emociones propias, provocadas por la retórica o la poesía, que son capaces de llevar al oyente y/o al espectador tanto al cambio de sus convicciones como a la liberación de su ánimo. La catarsis -en tanto que experiencia básica estético-comunicativa- corresponde tanto a la utilización práctica de las artes para su función social [...] como a la ideal determinación, que todo arte autónomo tiene, de liberar al observador de los intereses prácticos y de las opresiones de su realidad cotidiana, y de trasladarle a la libertad estética del juicio, mediante la autosatisfacción en el placer ajeno» (1986, 76).

Por su parte, la catastasis, siguiendo a Elder Olson, sería la dynamis particular de los textos cómicos, la catarsis de la comedia. Una sensación placentera que Olson define como «apaciguamiento del alma» $(1978,30)$, una relajación que se produce cuando se percibe el carácter absurdo del factor que nos producía tensión. 
entendimiento», en la que cristaliza la ambivalencia de la experiencia estética, pues la catarsis del Coloquio condujo a Peralta (y conduce al lector real de las Ejemplares) a «una identificación moral con una acción ejemplar» y, al mismo tiempo, le hace «perseverar en el simple placer de mirar» (Jauss 1986, 164), es decir, disfrutar despreocupadamente de los goces desinteresados que nos ofrece la ficción en tanto que ficción.

En el texto original, el uso del Casamiento como marco narrativo trasciende el uso técnico, pues modificará el sentido del Coloquio y lo situará «en un plano intermedio y ambiguo entre la realidad y la ficción, entre el sueño y la vigilia» (Gómez Trueba 1999, 303), elevando a una posición central la figura del alférez Campuzano, cuya peripecia con Estefanía de Caicedo cobrará también un nuevo significado. En el texto de Cerón, por el contrario, dado que los personajes del Casamiento son solo utilizados en tanto que garantes de la verosimilitud del relato, se ignora esta reflexión sobre la experiencia estética tanto en su aspecto productivo (la poiesis de Campuzano si le consideramos creador de la narración de Berganza) como en su función comunicativa (la catarsis de Peralta y, de nuevo, de Campuzano si, por el contrario, le consideramos mero transcriptor del Coloquio). Cervantes, por tanto, parece intervenir en la discusión sobre la utilidad y la inmoralidad de la novella italiana y defender, con la historia de la purgación del alférez a través del relato (inventado o no) de Berganza, las verdades morales que pueden entrañar los fingidos mundos posibles de la ficción literaria.

Ignorando la catártica narración enmarcada que proponía Cervantes en su novela, Cerón parece más interesado en la moral religiosa que en la literaria y, aunque Peralta acepte leer la nueva transcripción que Campuzano le ofrece, la purgación en cadena que dispuso Cervantes en el Coloquio original queda imposibilitada en la obra de su epígono, pues este despojará a la ficción transcrita por el alférez de todo su poder benéfico. Cerón, por tanto, al suprimir las vinculaciones entre los personajes del Coloquio y del Casamiento, no completará la reflexión metaficcional que Cervantes planteaba en torno a los efectos que la creación literaria puede tener sobre sus receptores (reales o ficticios). Así pues, resulta evidente que Cerón percibía ambas obras como creaciones temáticamente autónomas pues, en la prolongación firmada por el epígono granadino, este juego metaliterario es omitido por completo.

\section{3. «De lo que Cipión dijo a Berganza»: la construcción del relato picaresco}

Si el primer Coloquio apunta al perfeccionamiento moral de Berganza (que se refleja, como ya hemos señalado, en el del alférez Campuzano) sin excluir los diversos estadios de su evolución, el segundo, sin embargo, nos presentará un Cipión sin tacha, en todo momento prudente y devoto, cuya conducta 
hierática y moralmente uniforme contrastará con el dinamismo psicológico de su compañero canino.

Así pues, el proceso de aprendizaje por el que atraviesa Berganza no se verá replicado en la narración de Cipión, pues desde el comienzo de su relato se muestra como un perro moralmente más íntegro de lo que lo fuera aquel, neutralizando así cualquier posibilidad de gradación moral en la construcción del personaje. Por otro lado, los orígenes de Cipión no serán tan bajos como los del primero, pues en lugar de Sevilla nace en Jaén, «tierra de gente más sana» (Lauer 2016, 112), ciudad que nos presentará como noble y devota: «Yo nací en la ciudad de Jaén, bien conocida en España y aun en todo el mundo, que demás de su antigüedad y nobleza, por la grandiosa reliquia de que goza, que comúnmente dicen la cara de Dios, una de las tres que se estamparon en el lienzo de la mujer Verónica» (Carrillo Cerón 2013, 116).

Sin embargo, Cerón seguirá atentamente la organización del Coloquio original en el retrato de los primeros amos de Cipión. Nicolás el Romo, jifero cervantino y primer amo de Berganza, se verá replicado en la mondonguera del segundo Coloquio, cuyo marido es asimismo un desalmado jifero. Siguiendo la revisión de la estructura del Coloquio original de José Luis Álvarez Martínez, podemos situar tanto a Nicolás el Romo como a los primeros dueños de Cipión dentro del «ciclo de los instalados», es decir, dentro del grupo social que conformaban aquellas «personas que se hayan perfectamente integradas en la sociedad e instaladas en ella. Aunque, en muchos casos, actúan injusta e ilegítimamente, sin embargo, no son criticadas y perseguidas» (Álvarez Martínez 1994, 145).

Si bien los oficios de jifero y mondonguera (o tripera) eran completamente lícitos y estaban aceptados por la sociedad, serán retratados en ambos coloquios de manera negativa. No obstante, pese al nada halagüeño retrato que lleva a cabo Cerón de las prácticas de los primeros amos, no aludirá en ningún momento a la participación activa de Cipión en la rutina laboral del matadero. A diferencia de la plasticidad con que Cervantes nos presentaba el cometido de Berganza, pues recordemos que él y otros cachorros eran entrenados para que «arremetiésemos a los toros y les hiciésemos presa por las orejas» (1994, 302), Cipión asumirá en el segundo Coloquio el papel de un observador pasivo, que, con «la esportilla en la boca» esperando su ración, se limita a juzgar la crueldad con que su amo arremete contra las reses. De esta manera, introduciendo a un Cipión más digno de lo que lo fuera Berganza, que, según afirma, tras su entrenamiento por parte de Nicolás el Romo resultó ser «un águila en esto» $(1994,302)$, Cerón diluye la progresión moral del relato. Cipión no participará, por tanto, de la degradación ni de la bajeza moral del mundo que le rodea, muy al contrario, Carrillo Cerón se cuidará de mantenerle alejado de cualquier práctica deshonrosa.

Además, creemos intuir la voluntad satírica de Cerón al escoger una mondonguera como primera dueña de Cipión pues, siguiendo a Gómez Canseco, hasta bien entrado el siglo XVII «el oficio de tripera o mondonguera conllevaba alguna tacha de facilidad sexual. En realidad, en tanto que el mondongo 
aludía, en sentido burlesco y popular, al sexo masculino por su condición de tripa rellena, la olla del mondongo parece que representaba el sexo femenino» $(2006,389)$. Unas connotaciones sexuales que vuelven a ser síntoma de la degradación moral del mundo que rodea a Cipión, quien, sin embargo, será ajeno a todo ello. Recordemos, para evidenciar una vez más la distancia entre ambos coloquios, la tentación de la que parece ser preso Berganza al dejarse robar el trozo de carne que se le había encomendado guardar a manos de una «moza hermosa en extremo». El alano renuncia a defenderse de la joven «por no poner mi boca jifera y sucia en aquellas manos limpias y blancas», musitando tras el robo un lamento concupiscente: «La carne se ha ido a la carne» (1994, 304).

Efectivamente, a pesar de que Cervantes y Cerón esbozan un retrato muy similar del gremio de los jiferos y de que es posible leer ciertas correspondencias temáticas entre ambos episodios (desde la bajeza moral de los carniceros y sus vínculos con el hampa hasta ciertas connotaciones sexuales), la diferencia principal entre ambos textos estribará en el uso que Cerón hace del pícaro canino como un simple cronista de la degradación moral del mundo de la que, al contrario que al Berganza cervantino, no se le hará partícipe. Si bien ambas obras admiten ser leídas como representaciones estéticas de la realidad social de principios del XVII, que concedían a sus lectores la oportunidad de experimentar «el placer de descubrir la experiencia cotidiana como invención» (Rico 1988, 178), no propondrán, sin embargo, una misma solución ejemplar a los dilemas morales que la decadente España del Seiscientos planteaba a seres marginales como Berganza y Cipión ${ }^{23}$.

Así las cosas, resulta obvio que pueden aducirse ciertas similitudes con el género picaresco en el retrato que ambas novelas esbozan del inframundo marginal y de las capas más bajas de la sociedad del momento. Antes de aproximarnos al diferente tratamiento del componente picaresco en los textos de Cervantes y Cerón, conviene recordar las conclusiones a las que llegaba Jenaro Taléns en torno a la función transgresora de la picaresca, matizando los estudios a este respecto de Enrique Tierno-Galván:

El discurso picaresco no es, así, testimonio (aproximación sociologista) de una falsa movilidad social, enmascaradora de la lucha de clases y de la inmovilidad real, sino esa misma movilidad, o mejor, el juego simultáneo de intento de ascensión y de neutralización de esa lucha por la instauración de una estructura jerárquica que permita mantener el control en manos de la clase dominante. $Y$ es esa misma lucha, no ya reflejada, sino funcionando en el plano simbólico (ideológico) que es el específico del discurso li-

23. En torno a la relación de la literatura picaresca con la realidad sociopolítica del siglo XVII se recomienda acudir al volumen de Maravall (1986), donde encontraremos un análisis de los conceptos de pobreza y riqueza en la literatura áurea además de una revisión del individualismo del pícaro, así como de su aspiración por medrar en la jerarquía social. También hemos de remitir al estudio de Rico (2000), en el que el análisis de las características del género viene complementado por el análisis de la función y recepción de la novela picaresca en la España de los Austrias. 
terario, en general, y del picaresco en particular, cuyas constantes estructurales determina $(1975,38)$.

Asimismo, Taléns aclarará que el Coloquio de los perros de Cervantes es una novela "parapicaresca», pues utilizará «el espacio picaresco para desarrollar problemas distintos a los específicos del género» $(1975,40)^{24}$.

De esta manera, a pesar de que las aspiraciones del pícaro canino por llevar una vida desahogada y feliz se vean «neutralizadas [...] por la instauración de una estructura jerárquica», Cervantes no cederá a la conclusión derrotista que podría sugerir la estructura de la vida circular usual en los relatos picarescos, sino que acompañará el comentario satírico y trasgresor con la feliz invitación neoestoica al gobierno de uno mismo. La estructura cíclica propia del relato picaresco, en representación de la impenetrabilidad de las estructuras sociales, corre aquí en paralelo a una gradación ascendente representada en el progreso moral e intelectual de Berganza. Así, Carlos Blanco Aguinaga hablará de un realismo cervantino, ajeno al realismo de la novela picaresca, y con el que Cervantes, alejado de la perspectiva fatalista del Guzmán de Alfarache, no pretende imponer una visión uniforme de la realidad sino formularla en toda su complejidad porque «novelar no significa para Cervantes adjetivar, canonizar, decidir, juzgar, sino crear un mundo, a imagen del que percibimos, que, a partir de su creación, es libre de su creador, mundo fragmentario siempre, pero completo en cada fragmento» $(1957,341)$.

La evolución interior de Berganza no se ve replicada, sin embargo, en el Cipión de la segunda parte; de hecho, el continuador parece más interesado en hacer ascender a Cipión en el escalafón social que en el filosófico o en el moral. Carrillo Cerón indudablemente leyó la novela de Cervantes como una sátira a un inframundo altamente jerarquizado, lo que le condujo a componer una serie de episodios en los que se hiciese manifiesta esta ordenación de la sociedad, una serie de episodios de los que Cipión sería no solo el nexo de unión, sino también el comentador. El Coloquio de Cerón llevará a cabo una evidente estetización de los estratos más bajos de la sociedad, según las convenciones del género picaresco. Así lo expresa Roger Chartier:

De la misma manera que la iconografía del mundo al revés indicaba cómo debía pensarse el mundo al derecho, los textos que les atribuían una organización corporativa y monárquica a los marginados revelaban las categorías clasificadoras más fundamentales de los dominantes. Describir la extrañeza peligrosa y los desórdenes múltiples de los pícaros era una manera de reafirmar los principios que fundamentaban, o que debían fundamentar el orden familiar $(2002,14)$.

24. En torno a la cuestión del género del Coloquio de los perros, es indispensable acudir al estudio de Mancing (2000), en el que recoge las diferentes taxonomías con que los estudiosos se han referido al relato, siendo las mayoritarias las que lo califican de satírico, realista y picaresco. 
Un orden familiar que Cerón respeta escrupulosamente tanto en la jerarquización de los amos de Cipión como en la insistente vinculación de la ejemplaridad de su novela con la práctica de la religión católica, a juzgar por las profusas muestras de devoción que intercala a lo largo del texto. Así, al inicio del relato, Cerón hará asistir a Cipión, aún en Jaén, a la plaza de Santa María donde, como todo 15 de agosto, se muestra la Santa Verónica, reliquia que ya mencionó en su primera intervención. Por otra parte, Cipión abandonará a sus primeros amos para acompañar a unos pasteleros a la procesión de Nuestra Señora de la Cabeza, en Andújar, episodio en el que intercala un extenso romance en loa de la Virgen y, por último, tampoco dejará de llamarnos la atención el destino del último amo de Cipión, el estudiante de Villacastín, que determinará «de entrarse en religión para huir de las ocasiones del mundo» $(2013,153)^{25}$.

Así, la secuela de Cerón parece proponer una cristianización del original cervantino y, por extenso, de la novella italiana del Cinquecento, pues diluye en una ejemplaridad de signo contrarreformista los mundos ilimitados y falaces de la ficción literaria. De hecho, la resolución final del estudiante añadirá, evidentemente, un desenlace edificante a la sucesión de episodios que hemos recorrido junto al pícaro canino. Sin embargo, una vez más, este camino de perfección estará mejor ejemplificado en el mundo exterior a Cipión que en su propia conducta. La gradación moral del relato, en este caso, no se percibe en la evolución psicológica del alano, sino en la progresiva integridad moral de sus amos, tanto más cristianos cuanto mejor posicionados estén dentro de la organización corporativa propia de los marginados. En resumidas cuentas, Cipión, a diferencia del Berganza cervantino, no evoluciona, tan solo medra dentro del orden social establecido.

\section{4. "Que mi verdad sea sueño, y el porfiarla disparate»: Ginés Carrillo Cerón ante el aquelarre de la Camacha}

Si por un lado la desvinculación temática entre el Casamiento y el Coloquio y, por otro, la diferente aproximación al discurso picaresco hacen de la secuela de Cerón un texto menos complejo y transgresor que el de Cervantes, la tercera y última divergencia en la que nos detendremos nos permitirá completar nuestro acercamiento a ese dilema ideológico y literario al que, tal y como anticipamos, se enfrentó Cerón en su labor como continuador. Para ello, hemos de empezar llamando la atención sobre una de las réplicas de Berganza en el segundo Coloquio. Antes de narrar la historia de lo acaecido en Andújar, Cipión se excusará por dilatar la historia de su vida intercalando

25. Es posible intuir en la figura del estudiante una posible alusión a fray Antonio de Villacastín, religioso de la orden de san Jerónimo y obrero mayor de El Escorial. Entre las vidas de ambos parece haber ciertas correspondencias, no solo en su común patria segoviana sino también en su vocación espiritual, pues ambos parecen tomar el hábito tras haber sufrido las penalidades del mundo y como resultado de su afán por medrar. 
pequeños episodios anecdóticos como el de la romería de la Virgen de la Cabeza, a lo que Berganza responde:

Dila en hora buena, que no será molesta por ser novedad y que yo no he visto, demás de que todo esto son cosas buenas y santas, no como yo, que te conté lo que me dijo la vieja hechicera de Montilla de las que hacía la Camacha, y a mí me llamaba Montiel, teniéndome por hijo de la Montiela. Prosigue con tu cuento, que mejor es que los míos $(2013,124)$.

En este rotundo reproche a la obra de su predecesor cristalizarán los problemas temáticos y formales que la novela ejemplar de Cervantes planteaba a los lectores de su época. Efectivamente, Cerón, a través de Berganza, censurará el episodio central del primer Coloquio, en el que Cañizares le revela al alano que es hijo de la bruja Montiela, que alumbró a unos cachorros como fruto del maleficio de la vieja Camacha. Esta truculenta fantasía cervantina, radicalmente opuesta a los retratos costumbristas de prácticas religiosas con que Cerón salpica su Coloquio, proveería una explicación no exenta de polémica al enigma que rodea la capacidad de Cipión y Berganza para hablar y discurrir racionalmente. Cerón, por consiguiente, negaría el texto de Cervantes cuestionando, a través de uno de sus personajes, el decorum de su maestro por introducir un episodio alejado de esas «cosas buenas y santas» que, sin embargo, podremos leer en su continuación.

Así, creemos poder afirmar que la censura explícita a la que es sometido Cervantes en el texto de Cerón no es sino la manifestación de una encrucijada estética, cuyo epicentro teórico será la disputa en torno a los conceptos de $a d$ miratio y miraviglia, rechazados por Cerón, pero harto frecuentes en la prosa cervantina $^{26}$. De hecho, el hispanista escocés Edward C. Riley se referirá a la admiratio en Cervantes como «a sort of excitement stimulated by whatever was excepcional, whether because of its novelty, its excellence, or other extreme characteristics» $(1992,89)$ para, más adelante, llamar la atención sobre la tendencia cervantina a racionalizar lo maravilloso en sus novelas planteando, de esta manera, un ambiguo equilibrio entre lo insólito y lo verosímil.

Por otro lado, el inaudito alumbramiento de la Montiela no dejará de plantear una serie de tensiones frente a la estética realista del resto de episodios que componen la narración de Berganza. Las revelaciones de Cañizares, que Cervantes intercala en el centro de su Coloquio, abrirán una brecha en el relato picaresco que no hace sino evidenciar, a través de lo extraordinario, la causticidad del comentario satírico del texto. Si en los episodios anteriores y posteriores al de la bruja Cañizares, por su tono realista y sus similitudes con la novela picaresca, Cervantes permitía a sus lectores (citando a Rico de nuevo) disfrutar del «placer de descubrir la experiencia cotidiana como invención»

26. Véanse a este respecto las poéticas del Cinquecento de Francesco Patrizi (1969) y Torcuato Tasso (1959). Para un estudio más profundo en torno a los conceptos de admiratio y miraviglia durante los siglos XVI y XVII, se recomienda acudir a los volúmenes de Tatarkiewickz (2004) y Vega Ramos (1992). 
(1988, 178), en el insólito relato del aquelarre de la Camacha, por el contrario, tratará de sorprenderlos con un planteamiento manifiestamente inverosímil.

Cervantes, por consiguiente, utilizará la admiratio como una estrategia retórica que no solo estará al servicio del delectare, sino que también servirá para llamar la atención de los lectores sobre la necesidad de descodificar la verdadera naturaleza de los hechos que se presentan como insólitos. Por tanto, la negación del episodio de Cañizares por parte de Cerón en el segundo Coloquio cercenará el poder simbólico del hechizo de la Camacha, así como su interés exegético. La profunda ruptura que supone la inclusión del episodio de Cañizares en el Coloquio original queda subrayada por uno de los recursos narrativos más habituales de los Siglos de Oro, el del sueño literario ${ }^{27}$. Efectivamente, Cervantes se vale de la estructura onírica para enfatizar lo narrado haciendo holgadas concesiones a su libertad imaginativa sin perjudicar en exceso la verosimilitud del relato. A este respecto, Manuel María Pérez López se pregunta lo siguiente:

\begin{abstract}
¿Hasta qué punto la estructura onírica aporta una modificación, una matización del sentido de la obra? Si la transposición al plano imaginario se consuma, de modo que la realidad queda abolida, el mundo del sueño suplanta al mundo real y desempeña sus mismas funciones en el ámbito de la convención literaria [...]. Pero si, mediante artificios distanciadores que impidan esta suplantación se establece un dilema realidad-sueño, el resultado es una ambigüedad de efecto relativizador, más evidente cuando es reforzada por otros recursos $(1979,33)$.
\end{abstract}

Esa ambigüedad a la que se refiere Pérez López, que no es sino reflejo de lo incierto de la experiencia cotidiana, será la que envuelva los hechos acaecidos en el aquelarre de la Camacha. La dicotomía sueño-realidad sobre la que se fundamenta el Coloquio, que corre en paralelo a aquella racionalización de la admiratio de la que nos hablaba Riley $(1992,184)$, será una invitación a mirar de un modo diferente una realidad altamente jerarquizada (de la que se nos hace testigos a través de los constantes cambios de amo de Berganza) y que, sin embargo, es susceptible de ser deformada, deconstruida e interpretada de formas muy diversas. Cerón, en tanto que lector de Cervantes, se enfrentó al paradójico disfrute de lo abyecto y lo monstruoso en el Coloquio original ${ }^{28}$. Aquella estética de lo feo que estudiosos como Luciano Anceschi denominaban «mal gusto barroco», «delirio de mentes descompuestas y desnaturalizadas» o un «liberarse desenfrenado de la fantasía» (1991, 21-22), cumpliría una clara fun-

27. A fin de profundizar sobre el tema del sueño en la literatura barroca se aconseja acudir al estudio de Cvitanović (1969), en el que rastrea la significación del sueño fundamentalmente en la obra de Quevedo y Calderón, y, por otro lado, al volumen de Gómez Trueba (1999), en el que esboza una historia general del recurso onírico en la literatura española, deteniéndose especialmente en los Siglos de Oro.

28. Véase sobre la estética de lo feo y lo abyecto en el Coloquio cervantino el estudio de Forcione (1984), en el que analiza la utilidad de lo monstruoso dentro de la sátira y el papel de lo demoníaco dentro de la simbología religiosa que le atribuye al Coloquio. Por otro lado, se recomienda acudir al acercamiento de Alonso Palomar (1994) a la magia en la literatura de los Siglos de Oro, que puede servir de contextualización al episodio de la Camacha en el Coloquio cervantino. 
ción en la representación de ciertos contenidos sociales y morales, pues a fin de «eludir una realidad que no satisface se crea el asombro por medio de lo monstruoso, mientras que, al mismo tiempo, para aludir a una realidad que no gusta, el mejor método es recurrir a lo deforme» (Río Parra 2003, 16-17).

Este componente inverosímil, que en el texto de Cervantes se aproxima a lo deforme y a lo demoníaco, será explícitamente rechazado por Cerón. Al reivindicar los episodios que versen en torno a «cosas buenas y santas», el continuador parece aducir una solución distinta de la que nos propone Cervantes al problema de la representación literaria de las tensiones socioculturales y teóricoliterarias. El episodio de Cañizares se convertirá, así, en el punto de encuentro en el que confluirán los personajes del Coloquio y del Casamiento, bien para discutir la veracidad del relato, bien para admirarse de lo raro y peregrino del maleficio de la Camacha. Tal y como ocurre en el Quijote, donde Cervantes reúne en aquella célebre venta a representantes de todos los estratos sociales de la época para hacerles discutir en torno a si aquello que cubría la orgullosa cabeza de Alonso Quijano era yelmo o bacía de barbero, la disputa sobre la veracidad del insólito relato de Cañizares (entre Berganza y Cipión, primero, Campuzano y Peralta, después, y, por último, Cervantes y su lector) desdibujará y trivializará por un instante la distancia, no solo entre los estamentos sociales, sino también entre los diferentes planos de la ficción cervantina ${ }^{29}$.

Por consiguiente, nos conviene regresar a una posibilidad que planteábamos con anterioridad y que no hace sino avivar la discusión exegética en torno a la magia y lo inverosímil en el episodio de Cañizares. Efectivamente, tal y como apuntábamos antes, el primer Coloquio admite ser leído como la transcripción de un sueño de Campuzano, es decir, como una creación del propio alférez. De acuerdo con esta interpretación de la novela cervantina, no sería posible hablar de la catarsis de Campuzano, sino del placer de la poiesis que sufre el alférez (y el propio Cervantes) en tanto que fabulador y que, en último término, le reconciliaría con una realidad que le fue hostil (según lo narrado en El casamiento engañoso). Así, tanto Campuzano como Cervantes podrán, «mediante la creación artística, satisfacer su necesidad general de ser y estar en el mundo y sentirse en él como en casa, al quitarle al mundo exterior su fría extrañeza y convertirlo en obra propia alcanzando en esta actividad un saber, que se diferencia tanto del reconocimiento conceptual de la ciencia como de la praxis utilitaria de la manufactura en serie» (Jauss 1986, 76).

Cervantes hace explícito el proceso de poiesis por el que atraviesa Campuzano a través de la identificación del alférez con Berganza y su consecuen-

29. El encantamiento de la Camacha es lo que, en último término, posibilita el relato de Berganza, la purgación de Campuzano y la del lector de las Ejemplares y, al mismo tiempo, el comentario satírico de la novela de acuerdo con las reflexiones sobre la magia en el Coloquio de Francisco J. Sánchez: «Importa menos la veracidad de ello que la facticidad de su fenómeno. La magia y el sueño designan una realización de la imagen y una necesidad de su interpretación, una disposición estructurada de sus elementos y, sobre todo, se establecen como productores de un significado que es a la vez espiritual y material. Campuzano, enfermo y con fiebre, crea una historia dentro de la cual una bruja explica e interpreta la verdad radical de quienes cuentan la historia» $(1993,153)$. 
te evolución psíquico-moral. Volvemos, por tanto, a discutir aquella reflexión metaficcional a la que nos referimos previamente sobre los poderes benéficos de la novela de entretenimiento que Cervantes parece pergeñar en el Casamiento y en el Coloquio conjuntamente. Esta transcripción de un mal sueño, fruto de los delirios de un sifilítico, no es sino un intento del alférez (y, por extenso, de Cervantes) por domeñar un mundo que, a raíz del fraudulento matrimonio con doña Estefanía y de su propio pasado delictivo, concibe como despiadado e incomprensible. Así, frente a la pérfida naturaleza humana que se desprendía de los personajes del Casamiento (Campuzano incluido), el Coloquio concluirá con una reivindicación del aprendizaje, de la experiencia $\mathrm{y}$, en definitiva, de un modelo de integridad moral que parece apuntar al estoico dominio de uno mismo. Tanto Cervantes como Campuzano se valdrán, en este sentido, de la admiratio por medio de lo monstruoso y lo feo así como de la sátira menipea, es decir, de una estetización de la realidad sociocultural en la que ambos están irremediablemente inmersos.

Así pues, la decisión del estudiante de ingresar en un monasterio para «quitarse de servir y de las incomodidades de la vida» $(2013,152)$ con que concluye el texto de Cerón, enfrentará la experiencia religiosa de los personajes del segundo Coloquio a la experiencia estética de los del primero. Si en el texto original Berganza, Campuzano y el propio Cervantes alcanzaban una cierta sabiduría mediante la producción artística, es decir, haciendo de su experiencia vital una ficción, en el segundo Coloquio Cerón no mostrará interés en esa condición de homo artifex de Campuzano y, en cuanto a Cipión, propondrá una solución a sus dilemas morales más cercana al concepto de redención cristiana que a la poiesis cervantina.

El neoaristotélico Cipión y el escéptico Peralta, en tanto que exegetas de las historias que escuchan y leen en el primer Coloquio, sentirán la necesidad de rebatir su verosimilitud enfrentándose a «la voluntariedad de la comprensión estética del estilo» de la narración oral de Berganza y de la trascripción de Campuzano, respectivamente. Esta voluntariedad de la experiencia estética «demuestra la capacidad emancipatoria de su rebeldía, y explica el interés de las instancias dominantes por someter su fuerza esclarecedora y su seductora violencia» (Jauss 1986, 44). Cerón, sin embargo, al censurar explícitamente a Cervantes rechaza el comentario transgresor que propone la catarsis del Coloquio original. Este rechazo se concreta en la sustitución de la imaginería macabra y las ambiguas conclusiones del primer Coloquio por la liturgia tridentina y la «vocación de Nuestro señor» del estudiante de Villacastín.

\section{CONCLUSIÓN}

El Coloquio de los perros original concluye con el triunfo ético y estético de Berganza y Campuzano quienes, tras una vida de penalidades, logran humanizar una realidad otrora inhóspita y hostil por medio de sendas ficciones 
autobiográficas. Una solución que, como creemos haber demostrado, diverge en gran medida de la conclusión con que Cerón resuelve su secuela. Sin embargo, la resolución que propone el epígono, tan alejada de la original, será tan solo la culminación de un proceso de corrección del texto cervantino que está forzosamente ligado al contexto sociocultural y teórico-literario del siglo XVII.

Así, las tres divergencias sobre las que hemos fundamentado nuestro estudio, más allá de evidenciar dos formas distintas de novelar y, por extenso, de enfrentarse a la realidad del Seiscientos, apuntarán también al centro de la disputa teórico-literaria sobre la utilidad e inmoralidad de la novela corta. La reivindicación cervantina de los controvertidos modelos italianos quedará, de esta manera, enmascarada bajo la promesa de un deleite moralmente provechoso; sin embargo, tal y como parecen sugerir las modificaciones introducidas por Cerón en su prolongación, Cervantes se vale de manera consciente del poder catártico de su Coloquio para proponer una vindicación, no solo de la literatura de entretenimiento, sino también de la ruptura que esta propone con respecto al orden sociocultural vigente.

Las reflexiones vertidas en el prólogo a las Ejemplares en defensa de la literatura evasiva, así como del tiempo de ocio y del reposo intelectual y espiritual se concretarán, por tanto, en el Coloquio de los perros. Así pues, Cervantes parece ser plenamente consciente del poder de la ficción literaria que, si bien no puede transformar la realidad, por lo menos será capaz de modificar, para bien o para mal, la relación del hombre con el mundo que le rodea (sirva de ejemplo el sereno estoicismo de Berganza y Campuzano, pero también las enajenaciones más o menos lúcidas de Vidriera y Quijote). Si bien la novela ejemplar cervantina no ofrece, ni mucho menos, una conclusión susceptible de ser calificada de revolucionaria, los recelos de Cerón por adaptar algunos pasajes del texto original hacen evidente la percepción, por parte del epígono, de cierta intencionalidad subversiva en el discurso del maestro. Evidentemente, la prolongación de Cerón no puede aportarnos una visión unívoca de la recepción de que fue objeto el Coloquio de los perros a lo largo del siglo XVII; sin embargo, a la luz de las tres discrepancias que hemos analizado, creemos poder concluir que la ficción cervantina, última de aquellas doce «novelas más satíricas que ejemplares», pudo haber sido interpretada como una reivindicación del poder emancipador de la ficción literaria.

\section{BIBLIOGRAFÍA CITADA}

Abad, Francisco. 1987. «Retórica, poética y teoría de la literatura». Estudios románicos 4: 27-36.

Alonso Palomar, Pilar. 1994. De un universo encantado a un universo reencantado: magia y literatura en los Siglos de Oro. Valladolid: Grammalea.

Álvarez Martínez, José Luis. 1994. La estructura cíclica del coloquio de los perros. Mérida: Editorial Regional de Extremadura. 
Álvarez Roblin, David y Oliver Biaggini. 2017. La escritura inacabada. Continuaciones literarias y creación en España. Siglos XIII a XVII. Madrid: Casa de Velázquez.

Anceschi, Luciano. 1991. La idea del Barroco. Estudios sobre un problema estético. Madrid: Tecnos.

Aristóteles. 2007. Ética Nicomaquea. Barcelona: Gredos.

Bělič, Oldřich. 1977. Análisis de textos hispanos. Madrid: Editorial Prensa Española.

Blanco Aguinaga, Carlos. 1957. «Cervantes y la picaresca. Notas sobre dos tipos de realismo». Nueva Revista de Filología Hispánica 11 (3-4): 313-342.

Blasco Pascual, Javier. 2005. Cervantes: raro inventor. Alcalá de Henares: Centro de Estudios Cervantinos.

Cabrera, Vicente. 1972. «Nuevos valores de El casamiento engañoso y El coloquio de los perros». Hispanófila 45: 49-58.

Carrillo Cerón, Ginés. 2013. Segunda parte del Coloquio de los perros, edición y estudio de Abraham Madroñal. Alcalá de Henares: Centro de Estudios Cervantinos.

Casalduero, Joaquín. 1974. Sentido y Forma de las Novelas ejemplares. Madrid: Gredos.

Castro, Américo. 1948. «La ejemplaridad de las novelas cervantinas». Nueva Revista de Filología Hispánica 2 (4): 319-332.

Cervantes Saavedra, Miguel de. 1994. Novelas ejemplares Iy II, ed. Harry Sieber. Madrid: Cátedra.

Chartier, Roger. 2002. «La construcción de la realidad. Vagabundos y pícaros en la Edad Moderna». Tiempos modernos. Revista electrónica moderna 7: 1-15.

Colón Calderón, Isabel. 2001. La novela corta del siglo XVII. Madrid: Ediciones del Laberinto.

Cotarelo, Emilio. 1925. «Un novelista del siglo XVII e imitador de Cervantes, desconocido». BRAE 21: 640-651.

Cvitanović, Dinko. 1969. El sueño y su representación en el Barroco español. Bahía Blanca: Universidad Nacional del Sur.

Darnis, Pierre. 2013. «¿Por qué y cómo son ejemplares las Novelas ejemplares? (I) Una vuelta a los conceptos de mimesis y ética». Artifara. Revista de lenguas y literaturas ibéricas y latinoamericanas 13: 7-32.

Ehrlicher, Hanno. 2017. «Continuaciones y continuabilidad de la novela picaresca». En La escritura inacabada: continuaciones literarias y creación en España. Siglos XIII a XVII, eds. David Alvarez Roblin y Olivier Biaggini, 189-204. Madrid: Casa de Velázquez.

El Saffar, Ruth. 1976. Cervantes. El Casamiento engañoso and El coloquio de los perros. Londres: Grant \& Cutler in association with Tamesis Books.

Forcione, Alban K. 1984. Cervantes and the Mistery of Lawlessness. A study of El casamiento engañoso and El Coloquio de los perros. Princeton: Princeton University Press.

Frenk Alatorre, Margit. 1982 [2016]. «Lectores y oidores: la difusión oral de la literatura en el Siglo de Oro». Alicante: Biblioteca Virtual Miguel de Cervantes, edición digital a partir de Actas del séptimo Congreso de la Asociación Internacional de Hispanistas celebrado en Venecia del 25 al 30 de agosto de 1980, 101-123. Roma: Bulzoni.

Gandía Barceló, Mateo. 2018. "Sobre la construcción de los finales en la novela picaresca española”. AnMal Electrónica 45: 19-50.

García Berrio, Antonio. 1977. Formación de la teoría literaria moderna. Madrid: Cupsa. García de la Torre, Moisés. 1983. La prosa didáctica en los siglos de oro. Madrid: Playor. Garrido Domínguez, Antonio. 2007. Aspectos de la novela en Cervantes. Madrid: Compañía Española de Reprografía y Servicios.

Genette, Gérard. 1989. Palimpsestos. La literatura en segundo grado. Madrid: Taurus.

Gómez Canseco, Luis. 2006. «La comedia de Avellaneda». En El Siglo de Oro a escena. Homenaje a Marc Vitse, eds. Odette Grosse y Frederic Serralta, 383-394. Toulouse: Consejería de educación de la embajada de España en Francia. 
Gómez Redondo, Fernando. 1998. «Narradores y oyentes en la literatura ejemplar». En Tipología de las formas narrativas breves románicas medievales, eds. Juan Paredes y Paloma Gracia, 253-310. Granada: Universidad de Granada.

Gómez Trueba, Teresa. 1999. El sueño literario en España. Desarrollo y consolidación del género. Madrid: Cátedra.

González de Amezúa y Mayo, Agustín. 1912. El casamiento engañoso y el Coloquio de los perros: novelas ejemplares. Madrid: Bailly-Baillière.

González de Amezúa y Mayo, Agustín. 1956. Cervantes creador de la novela corta española: introducción a la edición crítica y comentada de las Novelas Ejemplares. Madrid: Consejo Superior de Investigaciones Científicas.

González Ramírez, David. 2016. «Materias deshonestas y de mal ejemplo. Programa ideológico y diseño retórico en la narrativa italiana del siglo XVI en España». En I novellieri italiani e la loro presenza nella cultura europea: rizomi e palinsesti rinascimentali, eds. Guillermo Carrascón y Chiara Simbolotti, 473-490. Roma: Accademia University Press srl.

González Ramírez, David. 2018. «La novela corta del Siglo de Oro en tela de juicio: la ejemplaridad y su función retórica (a propósito de la tradición medieval, los novellieri y las Novelas ejemplares de Cervantes)». eHumanista Cervantes 6 [número monográfico: 'España mi natura, Italia mi ventura': Cervantes e Italia, ed. I. Colón Calderón]: $56-92$.

Grilli, Giuseppe. 2004. Literatura caballeresca y re-escrituras cervantinas. Alcalá de Henares: Centro de Estudios Cervantinos.

Hinrichs, William. 2011. The Invention of the Sequel. Expanding Prose Fiction in Early Modern Spain. Woodbridge: Tamesis.

Ife, Barry W. 1985. Reading and Fistioning in Golden-Age Spain. A Platonist Critique and some Picaresque Replies. Cambridge: Cambridge University Press.

Jauss, Hans Robert. 1986. Experiencia estética y hermenéutica literaria. Ensayos en el campo de la experiencia estética. Madrid: Taurus.

Jurado Santos, Agapita. 2005. Obras teatrales derivadas de las novelas cervantinas (siglo $X V I I)$ : para una bibliografia. Kassel: Edition Reichenberger.

Lauer, A. Robert. 2016. «La segunda parte de El coloquio de los perros (1635) de Ginés Carrillo Cerón y su relación con El coloquio de los perros de Miguel de Cervantes: proceso y síntesis de un marco narrativo cervantino». Cervantes: Bulletin of the Cervantes Society of America 36 (2): 107-126.

Lázaro Carreter, Fernando. 1970. «Para una revisión del concepto 'novela picaresca'». En Actas del tercer Congreso Internacional de Hispanistas, coord. Carlos H. Magis, 27-45. México D. F.: El Colegio de México.

López Navia, Santiago. 2005. Inspiración y pretexto. Estudios sobre las recreaciones del Quijote. Madrid: Iberoamericana-Vervuet.

Lucía Megías, José Manuel. 1999. «La Pragmática de 1558 o la Importancia del Control del Estado en la Imprenta Española». Indagación: revista de historia y arte 4: 195-220.

Luttikhuizen, Frances. 1997. «¿Fueron censuradas las novelas ejemplares?». Cervantes: Bulletin of the Cervantes Society of America 17 (1): 165-174.

Madroñal, Abraham. 2011. «La segunda parte perdida del Coloquio de los perros, de Ginés Carrillo Cerón». Anales Cervantinos 43: 181-204. https://doi.org/10.3989/anacervantinos. 2011.007.

Madroñal, Abraham, ed. 2013. Ginés Carrillo Cerón, Segunda parte del Coloquio de los perros. Alcalá de Henares: Centro de Estudios Cervantinos.

Mancing, Howard. 2000. «Prototypes of Genre in Cervantes' Novelas ejemplares». Cervantes: Bulletin of the Cervantes Association of America XX, 2: 127-150. 
Maravall, José Antonio. 1986. La literatura picaresca desde la historia social. Siglos XVI y XVII. Madrid: Taurus.

Martín Morán, José Manuel. 2015. «La ejemplaridad de las novelas cervantinas a la luz de la teoría de la novella del Cinquecento». Criticón 124: 65-78.

Mata Induráin, Carlos. 2012. Recreaciones teatrales y alegorías cervantinas. Pamplona: EUNSA.

Mata Induráin, Carlos. 2013. Recreaciones quijotescas y cervantinas en la narrativa. Pamplona: EUNSA.

Miñana, Rogelio. 2006. La verosimilitud en el Siglo de Oro. Cervantes y la novela corta. Newark: Juan de la Cuesta.

Montauban, Jannine. 2003. El ajuar de la vida picaresca: reproducción, genealogía y sexualidad de la novela picaresca española. Madrid: Visor Libros.

Murillo, Luis A. 1988. «Narrative Structures in the Novelas ejemplares: An Outline». Cervantes: Bulletin of the Cervantes Society of America VIII, 2: 231-250.

Olson, Elder. 1978. Teoría de la comedia / Elder Olson. La comedia española del siglo de oro / Bruce W. Wardropper. Barcelona: Ariel.

Pabst, Walter. 1972. La novela corta en la teoría y la creación literaria. Madrid: Gredos. Parodi, Alicia. 2002. Las Ejemplares: una sola novela. Buenos Aires: Eudeba.

Patrizi, Francesco. 1969. Della Poetica. Edizione critica a cura di Danilo Aguzzi Barbagli. Florencia: Instituto Nazionale di studi sul rinascimento.

Pérez López, Manuel María, ed. 1979. Diego de Torres Villarroel, Los desahuciados del mundo y de la gloria. Madrid: Editorial Nacional.

Prieto, Antonio. 1986. La prosa española del siglo XVI. Madrid: Cátedra.

Rey Hazas, Antonio. 2003. «Género y estructura del Coloquio de los perros, o cómo se hace una novela». En Deslindes de la novela picaresca, 377-405. Málaga: Servicio de Publicaciones de la Universidad de Málaga.

Rico, Francisco. 1988. Problemas del Lazarillo. Madrid: Cátedra.

Rico, Francisco. 2000. La literatura picaresca y el punto de vista. Barcelona: Seix Barrall.

Rico Verdú, José. 1973. La retórica española de los siglos XVI y XVII. Madrid: CSIC.

Riley, Edward C. 1992. Cervantes' Theory of the Novel. Newark: Juan de la Cuesta.

Riley, Edward C. 2011. «Los antecedentes del Coloquio de los perros». En La rara invención. Estudios sobre Cervantes y su posteridad literaria, 239-253. Barcelona: Crítica.

Río Parra, Elena del. 2003. Una era de monstruos. Representaciones de lo deforme en el Siglo de Oro español. Madrid: Vervuert.

Rodríguez Guridi, Bárbara. 2008. «El carácter casi picaresco de las Novelas ejemplares». En Novelas ejemplares. Las grietas de la ejemplaridad, ed. Julio Baena, 127-160. Newark: Juan de la Cuesta.

Rubio Árquez, Marcial. 2013. «Los novellieri en las Novelas ejemplares de Cervantes: la ejemplaridad». Artifara 13 bis: 33-58.

Sánchez, Francisco J. 1993. Lectura y representación. Análisis cultural de las Novelas ejemplares. Nueva York: Peter Lang.

Spang, Kurt. 2005. Persuasión: Fundamentos de retórica. Pamplona: EUNSA.

Taléns, Jenaro. 1975. Novela picaresca y práctica de la transgresión. Madrid: Ediciones Júcar.

Tasso, Torquato. 1959. "Discorsi dell'arte poetica e in particolare sopra il poema eroico". En Prosel Torcuato Tasso; a cura di Ettore Mazzali, con una premessa di Francesco Flora. Milán: Ricardo Ricciardi, imp.

Tatarkiewicz, Władysław. 2004. Historia de la estética III. La estética moderna 1400-1700. Madrid: Ediciones AKAL. 
Utrera Bonet, María del Carmen. 2013. «La Pragmática del 1558 sobre impresión y circulación de libros en Castilla a través de los fondos de la Biblioteca de la Universidad de Sevilla». En Funciones y prácticas de la escritura: I Congreso de Investigadores Noveles en Ciencias Documentales, 277-282. Madrid: Universidad Complutense.

Vega Ramos, María José. 1992. El secreto artificio. Quilitas sonorum, maronolatría y tradición pontaniana en la poética del Renacimiento. Madrid: CSIC.

Vega Ramos, María José. 2013. «La ficción ante el censor. La novella y los índices de libros prohibidos en Italia, Portugal y España (1559-1596)». En Ficciones en la ficción: poéticas de la narración inserta (siglos XV-XVII), ed. José Valentín Núñez Rivera, 49-75. Bellaterra: Universidad Autónoma de Barcelona.

Wardropper, Bruce W. 1982 [2016]. «La eutrapelia en las Novelas ejemplares de Cervantes». Alicante: Biblioteca Virtual Miguel de Cervantes [edición digital a partir de Actas del séptimo Congreso de la Asociación Internacional de Hispanistas: celebrado en Venecia del 25 al 30 de agosto de 1980, 153-169. Roma, Bulzoni].

Zimic, Stanislav. 1996. Las Novelas ejemplares de Cervantes. Madrid: Siglo XXI.

Recibido: 14 de octubre de 2019

Aprobado: 15 de marzo de 2020 
